PNL-8143

UC-600

PNL- -8143

DE93 001344

\title{
FISCAL YEAR 1991 REPORT ON \\ ARCHAEOLOGICAL SURVEYS OF THE \\ 100 AREAS, HANFORD SITE, WASHINGTON
}

\author{
J. C. Chatters \\ H. A. Gard \\ P. E. Minthorn
}

September 1992

Pacific Northwest Laboratory

Richland, Washington 99352 


\section{EXECUTIVE SUMMARY}

In compliance with Section 106 of the National Historic Preservation Act (NHPA), and at the request of Westinghouse Hanford Company, the Hanford Cultural Resources Laboratory (HCRL) conducted an archaeological survey during FY 1991 of the 100-Area reactor compounds on the U.S. Department of Energy's Hanford Site. This survey was conducted as part of a comprehensive cultural resources review of 100-Area Comprehensive Environmental Response, Compensation, and Liability Act (CERCLA) operable units in support of CERCLA characterization activities. The work included a literature and records review and pedestrian survey of the project area following procedures set forth in the Hanford Cultural Resources Management Dlan (PNL-6942).

The 100-B/C, 100-D, 100-F, 100-H, 100-K, and $100-\mathrm{N}$ areas cover a total of $1834 \mathrm{ha}$, of which 770 ha remained undisturbed enough to warrant archaeological survey. Thirty-one cultural resource sites were found. Distribution of sites among the six areas is three in $100-\mathrm{B} / \mathrm{C}$, six in $100-\mathrm{D}$, eight each in $100-\mathrm{F}$ and $100-\mathrm{K}$, one in $100-\mathrm{H}$, and five in 100-N. Twenty-four of the sites were attributable to Native American activity and range in age from 7000 years to less than 50 years. Six of these--45BN149, 45BN150, 45BN151, 45BN176, 45BN179, and 45BN180-are currently included in or assignable to archaeological districts that are listed on the National Register of Historic Places. Six sites are the result of twentieth-century Euro-American activity and consist of the remains of homesteads and fields.

During FY 1992 and FY 1993, the sites that are not already on or eligible for the National Register of Historic Places will be evaluated following guidelines set forth in regulations pursuant to Section 106 of the NHPA. When needed, Requests for Determination of Eligibility, Findings of Effect and Adverse Effect, and plans for impact mitigation will be prepared and submitted to the Washington State Historic Preservation Officer, the Advisory Council for Historic Preservation, Native American tribes, and other interested parties. While evaluations progress, HCRL staff will continue archaeological surveys of the 100-HR-3 operable unit and a sample of the area lying between the 100-N Area and Gable Mountain. 


\section{CONTENTS}

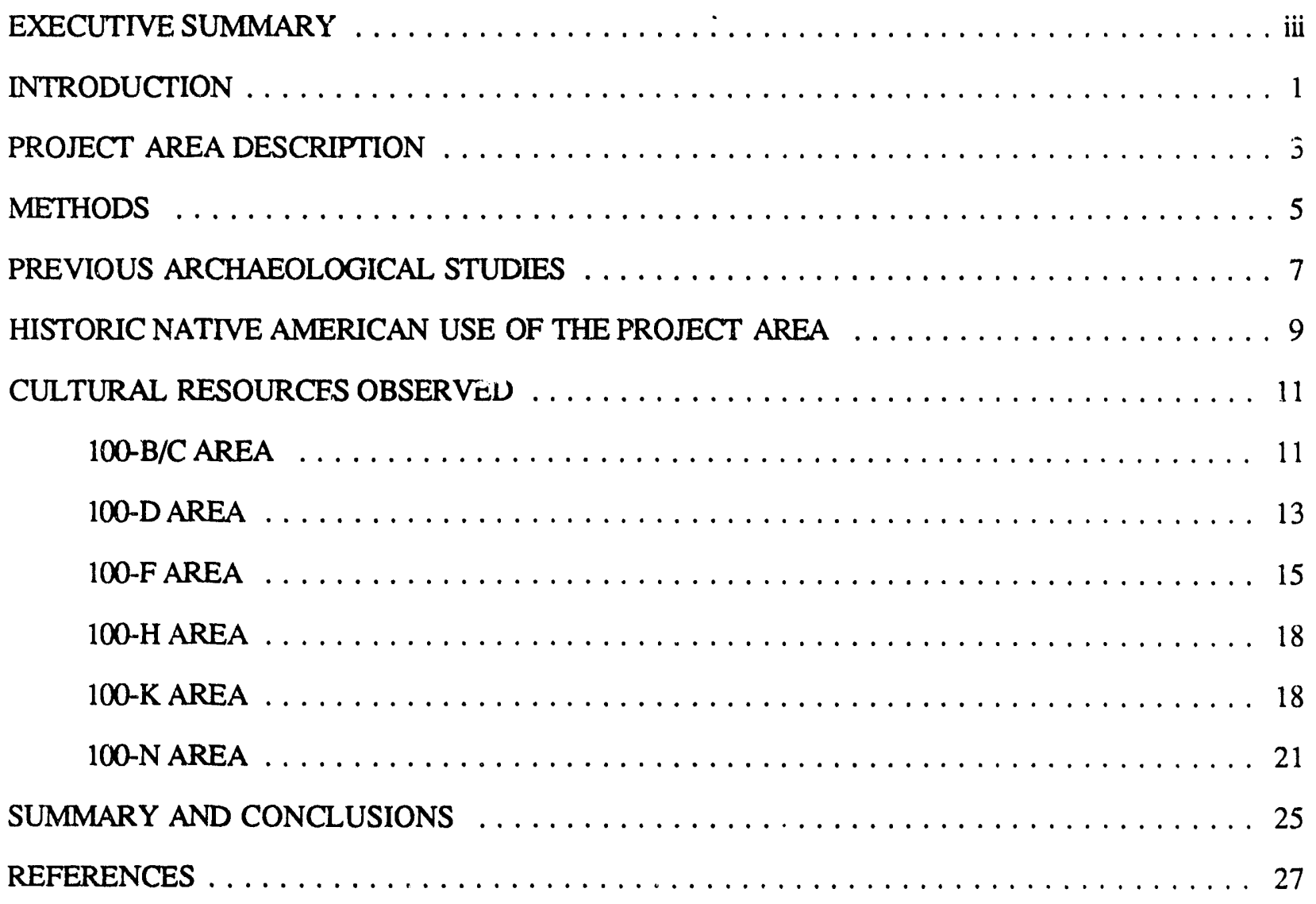




\section{FIGURES}

1 Map of the Hanford Site, Showing the Location of the 100 Areas $\ldots \ldots \ldots \ldots \ldots \ldots$

2 Areas Surveyed in the 100-B/C Area Shown on Portions of the U.S. Geological

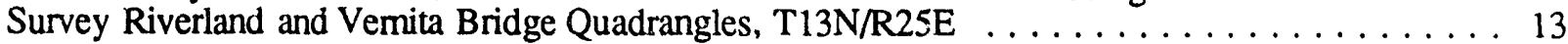

3 Areas Surveyed in the 100-D Area Shown on Portions of the U.S. Geological Survey Coyote Rapids Quadrangle, T14N/R26E . . . . . . . . . . . . . . . . . . . . . 14

4 Areas Surveyed in the 100-F Area Shown on Portions of the U.S. Geological

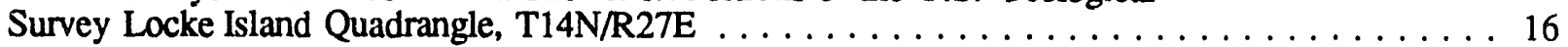

5 Areas Surveyed in the 100-H Area Shown on Portions of the U.S. Geological Survey Locke Island Quadrangle, T14N/R27E . . . . . . . . . . . . . . . . . . . . . . . . . 19

6 Areas Surveyed in the 100-K Area Shown on Portions of the U.S. Geological

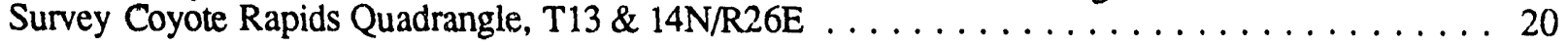

7 Areas Surveyed in the 100-N Area Shown on Portions of the U.S. Geological Survey Coyote Rapids Quadrangle, T13 \&14N/R27E

\section{TABLES}

1 Areas of the 100-Area Reactor Compounds and the Parcels Surveyed in Each $\ldots \ldots \ldots \ldots$

2 Archaeological Sites Discovered During the 1991 Archaeological Survey of the Hanford Site 100 Areas 


\section{INTRODUCTION}

The U.S. Department of Energy is conducting characterization studies of numerous Comprehensive Environmental Response, Compensation, and Liability Act (CERCLA) operable units on the Hanford Site, Washington. Among these are the 100-Area reactor compounds and their vicinities, including the $100-\mathrm{B} / \mathrm{C}, 100-\mathrm{D}, 100-\mathrm{F}, 100-\mathrm{H}$, $100-\mathrm{K}$, and $100-\mathrm{N}$ areas (Figure 1), which are scheduled for decommissioning, decontamination, and cleanup. Characterization studies, which entail excavation of multiple ground-water wells and surface radiological surveys, may potentially impact significant cultural properties, as also may the subsequent cleanup activities. Therefore, Section 106 of the National Historic Preservation Act (16 USC 470 et seq.), which specifies that federal land managers must consider the impact of any undertaking on significant historic properties, is applied. Historic properties are archaeological, historic, or cultural sites that meet criteria for nomination to the National Register of Historic Places. If no inventory of historic properties has been zonducted in the area of potential effect, such an inventory is to be conducted before initiating the undertaking.
In April 1990 Westinghouse Hanford Company (WHC) funded the Hanford Cultural Resources Laboratory (HCRL), which is operated by Pacific Northwest Laboratory, to initiate the Section 106 review of six 100-Area operable units. That work includes 1) a literature search to determine if previous archaeological surveys had been conducted in the vicinity of any of the operable units and, if so, what sites had been located; 2) an archaeological survey of any areas not previously inspected; and 3) interviews with knowledgeable members of local Native American tribes and bands to identify culturally important localities. Subsequent to identification of archaeological, historic, and cultural sites, evaluation of the sites' eligibility to the National Register of Historic Places is to be conducted. This report describes the result of the literature review and archaeological survey of the six operable units. Interviews with Native American informants have not yet been conducted because of scheduling problems. Sites identified during this survey and the subsequent interviews will be evaluated during FY 1992 and FY 1993. 


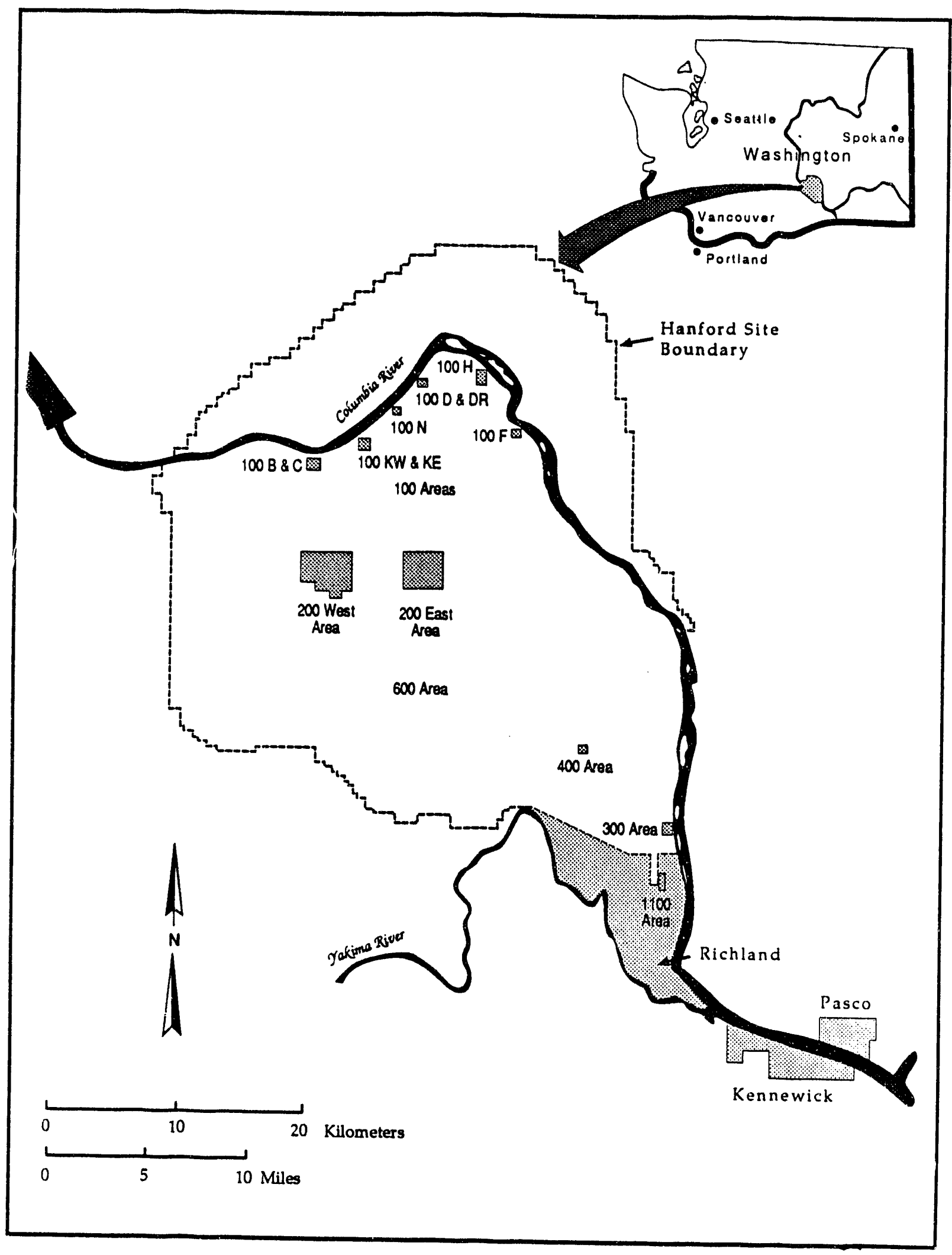

FIGURE 1. Map of the Hanford Site, Showing the Location of the 100 Areas 


\section{PROJECT AREA DESCRIPTION}

The operable units, which cover a total area of $1834 \mathrm{ha}\left(18.3 \mathrm{~km}^{2}\right)$ (Table 1) are topographically and environmentally similar. Each is situated along the Columbia River bank, with the reactor located on a high gravel terrace left by the recession of glacial floodwaters at the end of the Pleistocene. Shoreline areas grade from steep banks with narrow cobble beaches to broad, stepped, well-defined floodplain terraces with gently sloping beaches. The floodplain terraces consist of sand deposited during the Holocene (last 10,000 years) and occur on at least two levels, one dating to the early or middle Holocene and another representing the later Holocene. Inland areas are broad flats broken only by stabilized dunes. The area from west of the 100-N Area to the westem edge of the 100-D Area differs from his general pattern. In that vicinity are large, rounded gravel mounds formed when ice blocks, rafted downstream during catastrophic Pleistocene floods, deposited their sediment loads.

Vegetation on all sites is dominated by cheatgrass (Bromus tectorum), with scattered big sagebrush (Artemisia tridentata), tumble mustard (Sysimbrium spp.), Russian thistle (Salsola kali), rabbit brush (Chrysothamnus spp.), and needle and thread grass (Stipa comata). Small groves of deciduous trees and shrubs, usually black locust (Robinia pseudo-acacia), willow (Salix spp.), and mulberry (Morus spp.) grow along the river bank and at the sites of early twentieth-century homesteads.

TABLE 1. Areas of the 100-Area Reactor Compounds and the Parcels Surveyed in Each

\begin{tabular}{lcc} 
Area Name & Land Area (ha) & Surveved Area (ha) \\
\hline $100-\mathrm{B} / \mathrm{C}$ & 441 & 132 \\
$100-\mathrm{D}$ & 350 & 169 \\
$100-\mathrm{F}$ & 269 & 86 \\
$110-\mathrm{H}$ & 186 & 120 \\
$100-\mathrm{K}$ & 163 & 54 \\
$100-\mathrm{N}$ & 425 & 209 \\
Total & 1834 & 770
\end{tabular}




\section{METHODS}

This study consists of a literature and records review and surface survey. Procedures used in this endeavor follow specifications in the Hanford Cultural Resources Management Plan, Section 3.1.1 (Chatters 1989, pp. 3.2-3.12)

Literature review entailed a search of the HCRL's site survey files and archaeological site records. These records contain maps of previously surveyed areas and all recorded archaeological and historical sites. Literature on the nineteenth- and earlier twentieth-century human habitation of the Hanford Site was also reviewed to identify possible culturally important areas. Key references in this case were Relander (1956), Trafzer and Scheueman (1986), and Chatters (1989).

Archaeological survey consisted of first using aerial photographs to identify those areas that had not been entirely disturbed by facility construction and operation, then carefully inspecting those areas on foot. Of the total 1834 ha included in the project areas, 770 ha remained undisturbed enough that intact cultural resources could exist there. The remaining areas had been leveled, filled, and paved, making the surface occurrence of cultural resources predating 1943 extremely unlikely. Staff members searched the land surface in parallel transects spaced a maximum of $20 \mathrm{~m}$ apart, recording all observations. An archaeological survey form was completed for each reactor area and each artifact or site discovered. Sites were described, sketch mapped, and photographed. Artifacts important to site interpretation were also photographed, although no artifacts were collected. No excavations of any kind were conducted. Completed archaeological site forms were submitted to the Washington Office of Archaeology and Historic Preservation (OAHP) in Olympia, which maintains a complete file of prehistoric and historic archaeological sites for the state of Washington. Site numbers assigned by the OAHP begin with the designation "45BN" (meaning Washington, Benton County) for archaeological sites. Historic sites begin with $\mathrm{H}$ followed by a numeral for the county's place in alphabetical order (Benton County is 3). All survey records, photographs, and site forms are maintained by the HCRL. 


\section{PREVIOUS ARCHAEOLOGICAL STUDIES}

Surveys had not been conducted previously in most parts of the project area, although extensive surveys had been conducted up to area boundaries. Rice (1968) directed a survey by the MidColumbia Archaeological Society of the proposed Ben Franklin Dam reservoir pool, which included all lands below an elevation of $400 \mathrm{ft}(122 \mathrm{~m})$. Numerous sites were identified, including sites $45 \mathrm{BN} 149,45 \mathrm{BN} 150$, and 45BN151 between the $100-\mathrm{K}$ and $100-\mathrm{N}$ areas. These sites, two campsites and a cemetery (respectively), have been placed on the National Register of Historic Places as the Ryegrass Archaeological District. Rice also surveyed the area of the Hanford Generating

Plant, as part of investigations for the Washington Public Power Supply System in the late 1970s and early 1980s (Rice 1983). There, he identified and conducted test excavations at two archaeological sites, both of which are contiguous with $45 \mathrm{BN} 149$ and can be considered part of it. Site 45BN179 is a stratified campsite first occupied around
7000 years ago and finally used by the historic Wanapum band within the past 150 years. The second site, 45BN180, is a pair of small, late prehistoric house pits. Rice considered 45BN179 to be eligible for the National Register of Historic Places. Because the sites are legitimately thought of as part of an existing historic property, we will treat them as such. Altogether there are five recorded archaeological sites within the project areas, all of which are currently covered by the Ryegrass Archaeological District listing on the National Register of Historic Places.

In addition to surveys, the HCRL annually monitors a sample of the known archaeological sites and all cemeterics on the Hanford Site. All the sites described above have been inspected one or more times in the past 3 years and are still in much the same condition they were at the time of discovery (Chatters et al. 1990, 1991). 


\section{HISTORIC NATIVE AMERICAN USE OF THE PROJECT AREA}

It is customary in archaeological survey reports to include a description of the use made of the project area by Native Americans. This information is typically obtained from such books as Relander's Drummers and Dreamers (1956), which identifies numerous sites in the vicinity of the 100 areas, including Coyote Rapids, the berg mounds of the 100-N and 100-D areas, and the Columbia River shoreline opposite White Bluffs. In this case, however, we will defer the discussion of Native American use and culturally important areas until after the tribes have been consulted. 


\section{CULTURAL RESOURCES OBSERVED}

Twenty-five cultural resources, including 24 sites and one isolated artifact were found in the project areas. Six additional sites were identified previously by Rice (1968). The surveyed portions of each area and the sites found there are described in this section. Table 2 lists the sites, site type, and age.

\section{0-B/C AREA}

The 100-B/C Area consists of approximately 441 ha, of which 133 ha (30\%) were surveyed (Figure 2). More than $99 \%$ of this operable unit is on the gently sloping Pleistocene terrace ranging from $133 \mathrm{~m}$ above sea level on the north edge to $153 \mathrm{~m}$ at the southem boundary. The remainder of the area is a steeply sloping bank (10:1 grade) that extends down to the Columbia River shoreline. At low water an extensive gravel beach is exposed along the north boundary of the operable unit. On the upstream end of the operable unit, the bank is less steep, broadening into a gently sloping (50:1 grade) gravel flat $150 \mathrm{~m}$ wide. As with all of the operable units, survey efforts were concentrated along the shoreline and the undisturbed periphery around the reactor complex. Two sites (45BN446 and $\mathrm{H} 3-17$ ) and a single isolated artifact (45BN430) were found.

45BN446. Site $45 B N 446$ is located on the northern edge of the Pleistocene terrace, just above the river bank, and among the gravels of the exposed river channel directly below. Sediment consists of fine micaceous sand inter bedded with fluvially deposited gravel and cobbles. Ground cover ranges from $40 \%$ to $60 \%$, and is composed of grasses and sagebrush. Cultural material is visible in two areas. Along the cobble shoreline is a light density scatter of fire-cracked rock (FCR), flakes, and net weights; on the terrace edge and slope, shell fragments occur in ant hills, indicating the presence of buried deposits. The site measures approximately $60 \mathrm{~m}$ by $250 \mathrm{~m}$ based on the distribution of surface materials. The depth of the deposit on the terrace is unknown, but is probably less than $1 \mathrm{~m}$. Thirty-five items were found exposed on the surface, with a maximum density of 10 per square meter. Based on its topographic setting, the occurrence of net weights and the high quantity of shell, this site probably dates to the Frenchman Springs Phase of local prehistory (2500-4500 B.P.). Although there has been some surface disturbance from heavy equipment, the majority of the deposit appears to be largely intact as a result of the depth of the cultural layer below surface. Testing to refine the site boundaries and to determine depth, age, and significance is scheduled for October 1992.

H3-17. Historic site $\mathrm{H} 3-17$, which lies in the northeasternmost comer of the Pleistocene terrace, is a 1910 to 1943 farmstead characterized by furrowed fields, buried and exposed wooden water mains, heaps of field cobbles, and discrete concentrations of domestic debris. Piles of white granite stones are interspersed throughout the irrigated field and appear to be field markers. The site measures $100 \mathrm{~m}$ by $350 \mathrm{~m}$ with cultural material extending to perhaps $1 \mathrm{~m}$ in depth. More than 50 artifacts were noted, including a cast iron skillet, a wash basin, buckles, horse tack, milk bottles, a tractor scoop, 1940s license plates, abundant fragments of wooden irrigation pipe, and numerous glass shards. Rock walls composed of cleared field cobbles delineate the boundaries of the farm. Currently, $60 \%$ of the area is covered by steppe vegetation. Sediments are fine sand mingled with coarse flood gravel and cobbles. Post-abandonment disturbances have been caused by heavy equipment, either during the construction of B Reactor or possibly during the Hanford cleanup activities conducted during the mid-1970s.

45BN430. An isolated medial/basal fragment of a tan/brown chert projectile point was found lyirig on the low gravel bar in the northwest part of the operable unit. The ground surface consists of compacted fluvial gravel and cobbles. No other cultural material was discovered in the vicinity of the isolate. Based on stylistic attributes 
TABLE 2. Archaeological Sites Discovered During the 1991 Archaeological Survey of the Hanford Site 100 Areas

\begin{tabular}{|c|c|c|c|}
\hline Operable Unit & $\begin{array}{l}\text { Temporary } \\
\text { Number }\end{array}$ & $\begin{array}{c}\text { Washington } \\
\text { Number }\end{array}$ & Site Type/Age \\
\hline $100-\mathrm{B} / \mathrm{C}$ & HT-91-029 & $45 \mathrm{BN} 446$ & Frenchman Springs (ca 2500-4500 B.P.) \\
\hline $100-\mathrm{B} / \mathrm{C}$ & HT-91-034 & $\mathrm{H} 3-17$ & Farm Complex \\
\hline $100-\mathrm{B} / \mathrm{C}$ & HT-91-006 & $45 \mathrm{BN} 430$ & Prehistoric Isolate \\
\hline $100-D$ & HT $-91-026$ & $45 \mathrm{BN} 442$ & Prehistoric Caim \\
\hline $100-D$ & HT-91-027 & $45 B N 443$ & Prehistoric Cairn \\
\hline $100-D$ & HT-91-028 & $45 B N 444$ & Prehistoric Caim \\
\hline $100-D$ & HT $-91-022$ & $45 \mathrm{BN} 439$ & Frenchman Springs (ca $2500-4500$ B.P.) \\
\hline $100-\mathrm{D}$ & HT-91-025 & $45 \mathrm{BN} 459$ & Frenchman Springs (ca 2500-4500 B.P.) \\
\hline $100-D$ & HT-91-037 & $45 \mathrm{BN} 416$ & Cayuse Phase camp $(<2500$ years $)$ \\
\hline $100-\mathrm{F}$ & HT-91-013 & $\mathrm{H} 3-11$ & Homestead \\
\hline $100-\mathrm{F}$ & HT-91-031 & $\mathrm{H} 3-12$ & Homestead \\
\hline $100-F$ & HT $-91-032$ & $\mathrm{H} 3-13$ & Homestead \\
\hline $100-\mathrm{F}$ & HT-91-033 & $\mathrm{H} 3-14$ & Homestead \\
\hline $100-\mathrm{F}$ & HT-91-014 & $45 B N 435$ & Cascade Camp (ca 4500-7000 B.P.) \\
\hline $100-\mathrm{F}$ & HT-91-016 & $45 B N 433$ & Prehistoric Campsite \\
\hline $100-\mathrm{F}$ & HT $-91-017$ & $45 \mathrm{BN} 432$ & Prehistoric Campsite \\
\hline $100-\mathrm{F}$ & HT $-91-018$ & $45 \mathrm{BN} 431$ & Prehistoric Campsite \\
\hline $100-\mathrm{H}$ & none & $45 \mathrm{BN} 176(1)$ & Wanapum Fishing Camp \\
\hline $100-K$ & HT-91-006 & $45 \mathrm{BN} 423$ & Cascade Camp (ca 4500-7000 B.P.) \\
\hline $100-K$ & HT-91-020 & $45 B N 434$ & Cascade Camp (ca 4500-7000 B.P.) \\
\hline $100-K$ & HT-91-015 & $45 \mathrm{BN} 115$ & Cascade Camp (ca 4500-7000 B.P.) \\
\hline $100-K$ & HT-91-007 & $45 \mathrm{BN} 424$ & Historic Wanapum Village \\
\hline $100-\mathrm{K}$ & HT.91-009 & unassigned & Fishing Camp \\
\hline $100-K$ & HT-91-019 & $\mathrm{H} 3-10$ & Farmstead \\
\hline $100-K$ & none & $45 \mathrm{BN} 150(1)$ & Prehistoric Campsite \\
\hline $100-K$ & none & $45 \mathrm{BN} 151^{(1)}$ & Wanapum Cemetery(1) \\
\hline $100-\mathrm{N}$ & HT-91-010 & $45 \mathrm{BN} 437$ & Cairn \\
\hline $100-N$ & HT-91-011 & 45BN438 & Cairn \\
\hline $100-\mathrm{N}$ & none & $45 \mathrm{BN} 149(1)$ & Prehistoric Camp \\
\hline $100-\mathrm{N}$ & none & $45 \mathrm{BN} 179(1)$ & Prehistoric Camp and Village \\
\hline $100-\mathrm{N}$ & none & $45 \mathrm{BN} 180(1)$ & Late Prehistoric Village \\
\hline
\end{tabular}

(1) Sites listed on or considered eligible for listing on the National Register of Historic Places. 


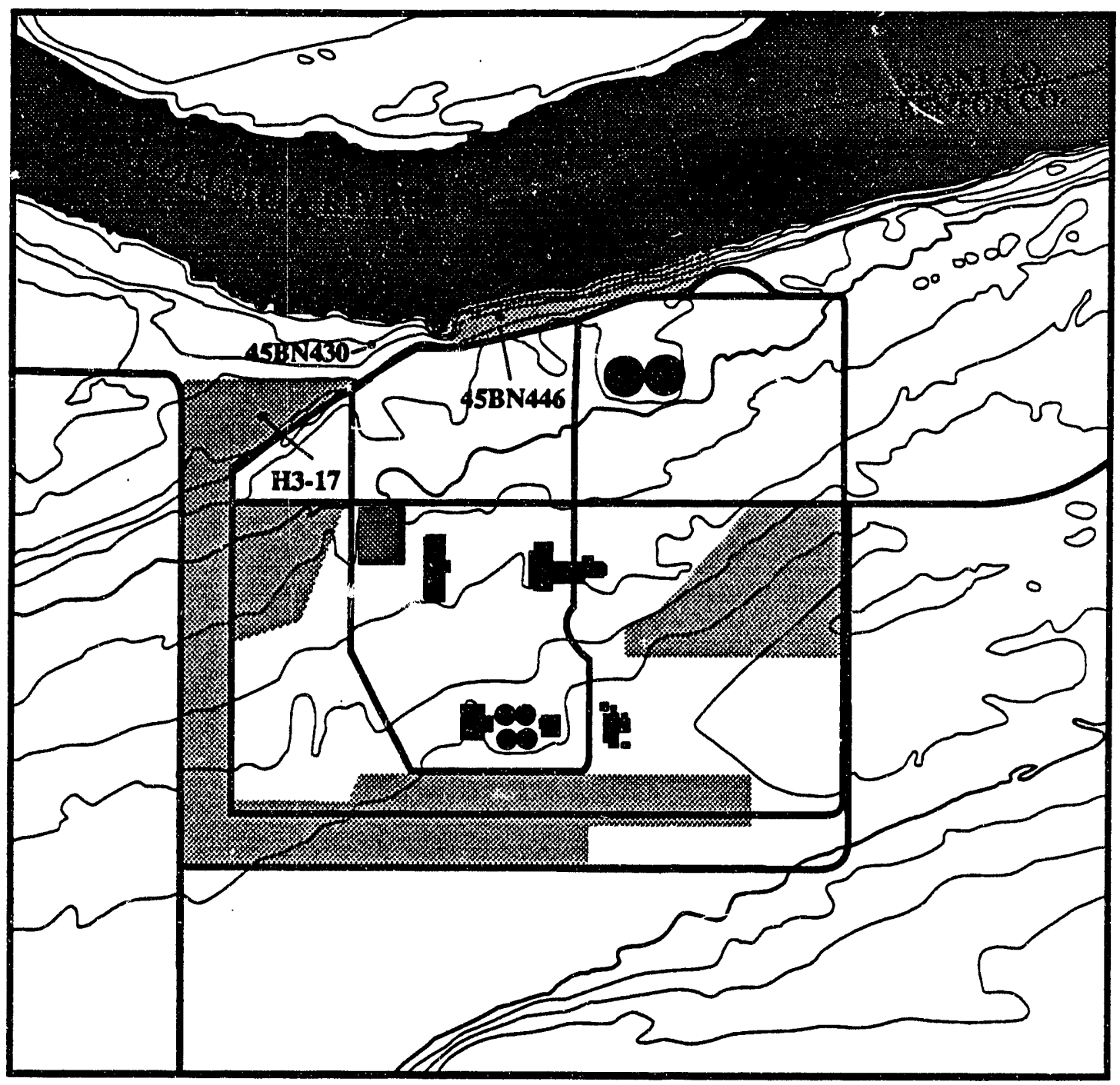

FIGURE 2. Areas Surveyed (Shaded) in the 100 B/C Area Shown on Portions of the U.S. Geological Survey Riverland and Vemita Bridge Quadrangles, T13N/R25E

the point appears to belong to the Cold Springs Side-Notched type, which dates from 4500 to 7000 years B.P. (Lohse 1985).

\section{0-D AREA}

The 100-D Area consists of approximately $350 \mathrm{ha}$, nearly half (169 ha) of which was surveyed (Figure 3). This operable unit covers four terrace levels, two of Pleistocene age and two attributable to the Holocene, and a small unnamed island in the Columbia River. The uppermost surface is nearly level, with elevations ranging from 142 to $144 \mathrm{~m}$ above sea level. In the northeast comer of the operable unit, this terrace slopes at a gradient of $30: 1$ to the second level, the elevation of which is from 137 to $134 \mathrm{~m}$. Berg mounds occur in the extreme westem edge of the upper terrace. These are 50 to $100-\mathrm{m}$-long by $<50$-m-wide oblong mounds up to $6 \mathrm{~m}$ above grade. The lower Pleistocene terrace lacks such features. Both Pleistocene terraces consist of gravel overlain irregularly by eolian sand. At the northeastem corner, along the northern edge of the second Pleistocene terrace, a 10:1 slope drops to the older of two Holocene terraces, which has an upper elevation of $127.5 \mathrm{~m}$. This terrace is made up of 


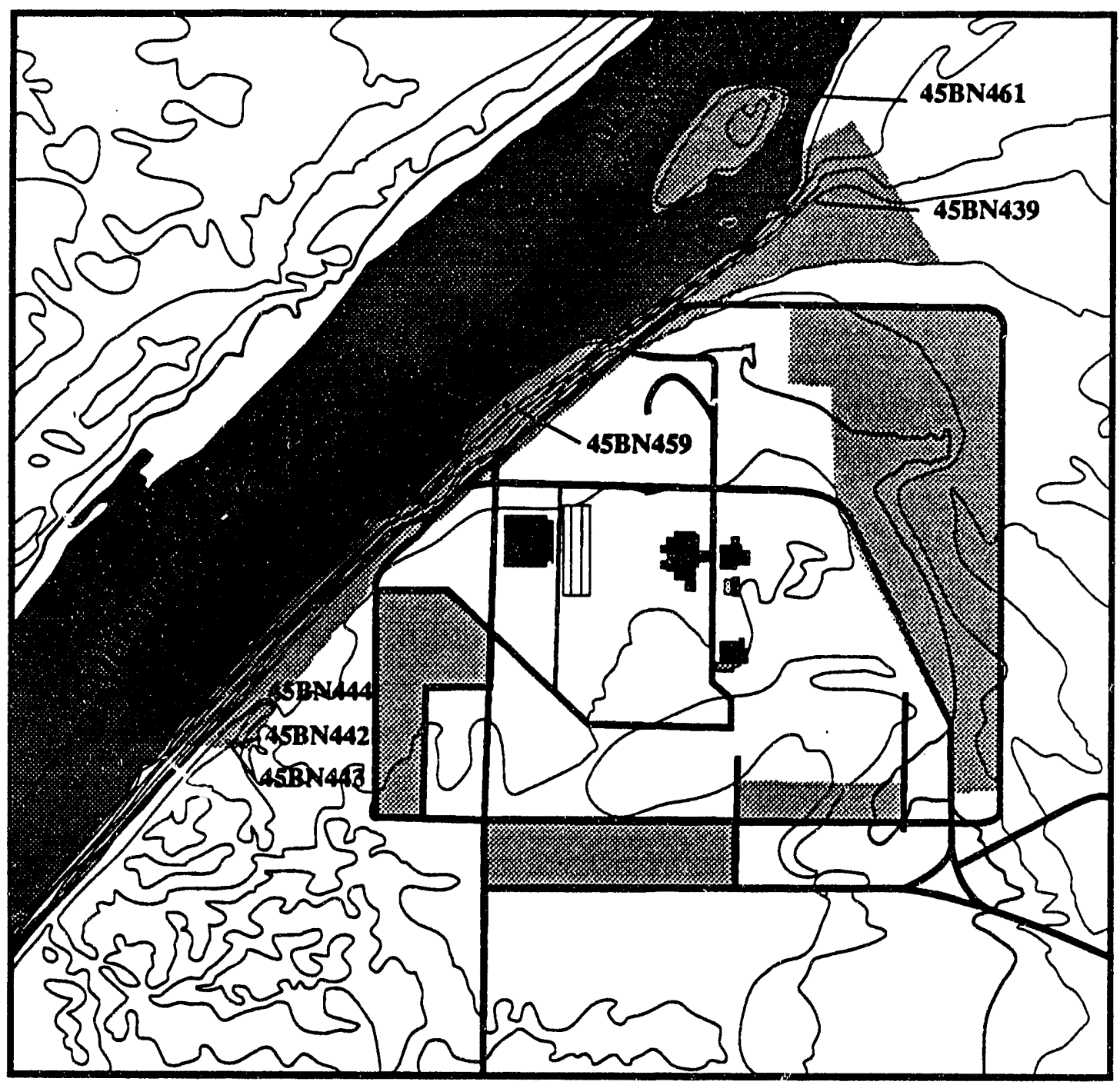

FIGURE 3. Areas Surveyed (Shaded) in the 100-D Area Shown on Portions of the U.S. Geological Survey Coyote Rapids Quadrangle, T14N,R26E

river-deposited sand with a depth of at least $1.5 \mathrm{~m}$. Along the center of the northwestern edge of the operable unit is a lower, therefore younger Holocene terrace. In this area the upper Pleistocene terrace ends at a 5:2 slope, below which the youngest terrace occurs at an elevation of $120 \mathrm{~m}$. This elliptical cobble and coarse sand surface is $500 \mathrm{~m}$ long by $75 \mathrm{~m}$ wide. The island, measuring $400 \mathrm{~m}$ long by $150 \mathrm{~m}$ wide and reaching an elevation of $122 \mathrm{~m}$, consists primarily of gravel and cobbles, but has a stratified deposit of fluvial sand at its downstream end.

Six prehistoric sites were located within the 100-D Area. Three sites (45BN442, 45BN443, and 45BN444) are caims, sites 45BN439 and
45BN459 date from the Frenchman Springs Phase, and site 45BN416 is of indeterminate age at this time. Sites 45BN148 and 45BN147 were previously recorded in the area by Rice (1968).

45B 1416 . Site 45BN416 is situated on a small island next to the 100-D Reactor and consists of FCR, debitage, small cobble caims, and fragments of Margaritifera mussel shell. The site measures $300 \mathrm{~m}$ by $140 \mathrm{~m}$, which is the majority of the island. The depth of the deposit may reach $50 \mathrm{~cm}$ below surface. More than 100 items were noted with a maximum density of 25 objects per square meter. Surface sediments consist of a cobble pavement interspersed with very fine to medium fine sand. Rabbitbrush covers $20 \%$ to $25 \%$ of the 
site. This site appears to date from the Cayuse Phase (2500 years B.P. to contact). Testing is scheduled for late winter of 1992.

45B $\mathrm{B} 442$. Site $45 B N 442$ consists of two large caims $1 \mathrm{~m}$ apart located on the top of a berg mound at the eastemmost extent of these topographic features. The locally scavenged cobbles that make up the cairns are covered with lichen, indicating that these features predate the nineteenth century. Caims have a high cultural value to the local Native American groups, commemorating personal religious spirit quests, or marking graves. The northermmost caim contains approximately 44 stones arranged around a 17-cm-deep depression. The entire feature is $2.5 \mathrm{~m}$ long by $2.0 \mathrm{~m}$ wide. The southem caim contains approximately 50 stones and is $2.4 \mathrm{~m}$ long by $2.1 \mathrm{~m}$ wide.

45BN443. Similar to 45BN442, site $45 B N 443$ is situated on the apex of a rounded berg mound. This single caim is composed largely of basalt and granite cobbles heavily covered with lichen. There are two large boulders, one at the center and one at the northwest periphery. Five river cobbles are distributed along the outer edges. Fifty-five stones were used to construct the cairn, which measures $2.9 \mathrm{~m}$ by $2.0 \mathrm{~m}$ by $28 \mathrm{~cm}$. A single cryptocrystalline silicate (CCS) tertiary flake was found near the caim.

45 B N444. This cairn is situated on a small rounded hill at the northwestern edge of the higher Pleistocene terrace, adjacent to the Columbia River. It consists of approximately 80 to 90 basalt cobbles averaging 30 to $40 \mathrm{~cm}$ in diameter. The caim measures $3.2 \mathrm{~m}$ by $2.1 \mathrm{~m}$ and is about $40 \mathrm{~cm}$ high. All stones are $90 \%$ lichen covered, indicating prehistoric age for the caim. A spalled white cobble is situated at its north end and a brown split cobble is placed at its south end. The caim is depressed at its center, which may indicate that it marks a grave.

45BN 439. This site is situated on the older Holocene terrace near the northeasternmost edge of the operable unit. Cultural material is exposed within a borrow pit at the downstream end of the site and appears periodically upstream in the terrace bank. The site lies in fluvial sand, extending from $30 \mathrm{~cm}$ to as much as $150 \mathrm{~cm}$ below the surface. The site is characterized by Margaritifera mussel shell scatters and lenses, stone tools, cores, and FCR. Artifacts noted were two CCS cores, the distal end of a pentagonal knife, a hammer stone, and numerous spall knives. Additionally, at least
500 pieces of debitage (stone waste flakes) were noted, principally secondary and tertiary flakes of CCS. Density reached 25 flakes per square meter. Based on visual evidence and the extent of the terrace, the site measures $355 \mathrm{~m}$ by $86 \mathrm{~m}$. Based on the occurrence of the pentagonal knife, the site dates to the Cayuse or Frenchman Springs Phase, or perhaps both (later than 4500 B.P.). Ground cover averaged $50 \%$. Considerable postdepositional disturbance has occurred. A large borrow pit occurs at the site's eastern end, and two roads traverse the site farther to the west. Nevertheless, a large part of the site appears to be intact. Testing is scheduled for late 1992 or early 1993.

45B N459. This site is separated from 45BN439 by an erosion scar down the terrace embankment and may well be an extension of that site. It covers the entire younger Holocene terrace, which is a gravel surface frequently washed by spring floods. Cultural material consists principally of concentrations of spalled cobbles and FCR, which are scattered among the gravels of the terrace. One hopper-mortar base, $26.6 \mathrm{~cm}$ in diameter and $8.9 \mathrm{~cm}$ high, was noted on the shoreline at the downstream end of the site.

Including FCR, the total number of cultural $500 \mathrm{~m}$ materials was more than 100 , with a maximum density of 10 per square meter. The site measures by $60 \mathrm{~m}$ and appears to be surficial; all material is scattered across a compacted cobble pavement. Ground cover ranges from $30 \%$ to $40 \%$ and consists of cheatgrass, mustard, and Russian thistle. No disturbance was noted.

\section{0-F AREA}

The 100-F Area covers 269 ha, of which 86 ha (32\%) were surveyed (Figure 4). Topography of the area is essentially flat, with the river bank dropping precipitously. Although the local geology has not been described, the area appears to consist of a broad, early Holocene floodplain that has an elevation of $125 \mathrm{~m}$. This floodplain consists of finely bedded fine sand and silt deposits that are as yet undated.

Eight archaeological sites were recorded, four of them historic and four prehistoric. Sites H3-11, H3-12, H3-13, and H3-14 are all turn-ofthe-century homesteads, while sites 45BN431, $45 \mathrm{BN} 432$, and $45 \mathrm{BN} 433$ are of undetermined age. Site 45BN435 dates from the Cascade Phase. 


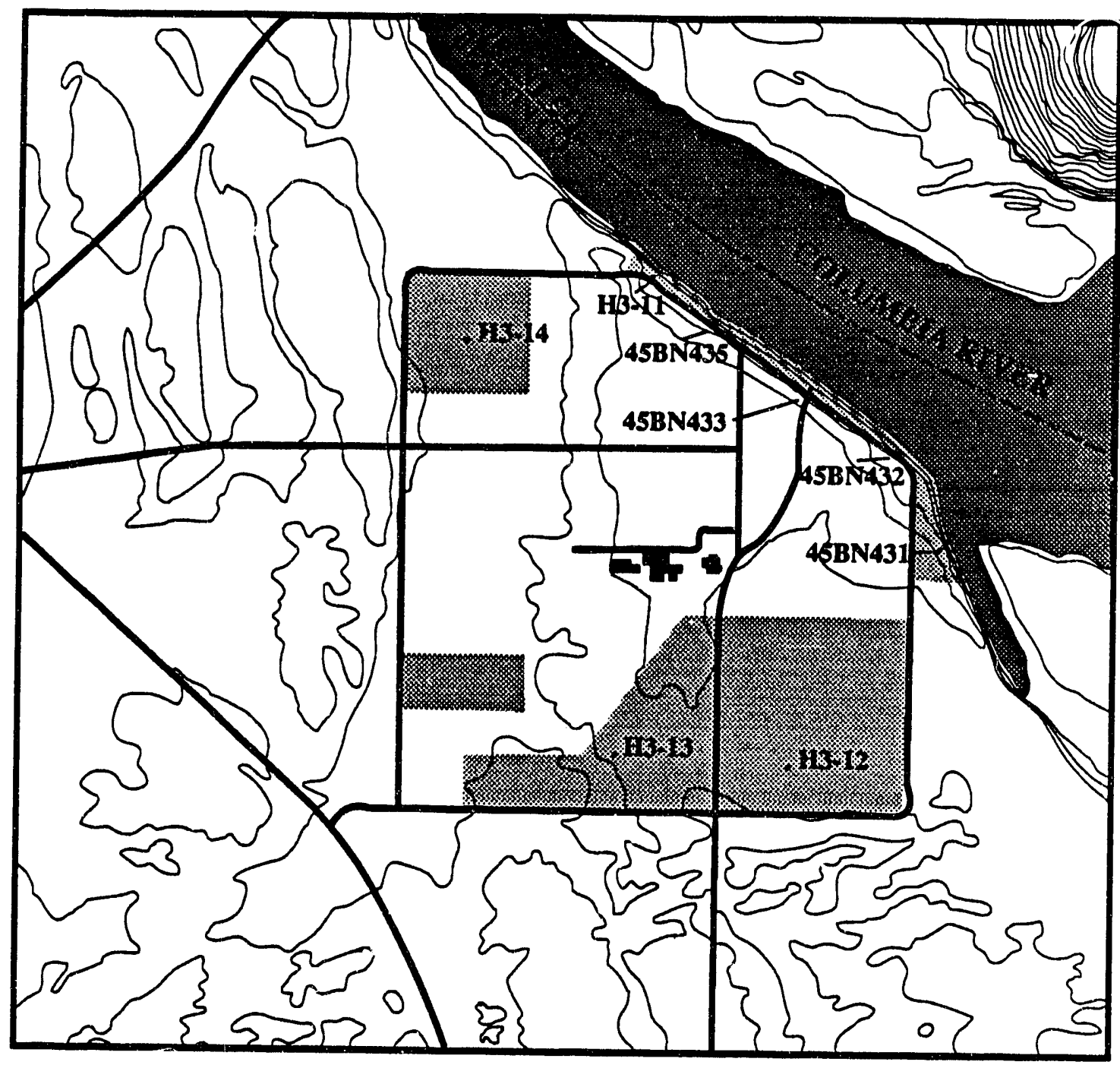

FIGURE 4. Areas Surveyed (Shaded) in the 100-F Area Shown on Portions of the U.S. Geological Survey Locke Island Quadrangle, T14N/R27E

H3-11. This is a light scatter of historic debris situated on top of a high river terrace overlooking the Columbia River. The site measures $28 \mathrm{~m}$ by $10 \mathrm{~m}$. The depth of the deposit is unknown, but does not appear to extend beyond a few centimeters. The total number of artifacts exceeds 75 , with densities reaching 25 objects per square meter. Some of the artifacts noted are a flow blue stoneware plate, crimped sanitary cans (which are tins for storing kippered herring, cookies, and sardines), a leather boot, tobacco tins, white stoneware plates, and fragments of aqua-green glass. Based on the age range of these artifacts, the site appears to date from the late 1920 s or 1930 s. Ground cover averages $80 \%$. Surface sediments consist of fluvial sediments, principally fine sand and fist-size water-wom cobbles. The site has been severely impacted, probably by reactor construction or during the Hanford cleanup.

H3-12. Site H3-12 consists of two loci separated by $50 \mathrm{~m}$. The access road is $70 \mathrm{~m}$ west of Locus $\mathrm{A}$, and an irrigation ditch connects the two loci. Both loci contain evaporated milk cans and broken bottles, but a larger number of intact objects occurs in Locus A. The two areas measure $15 \mathrm{~m}$ by $15 \mathrm{~m}$ (Locus $\mathrm{A}$ ), and $10 \mathrm{~m}$ by $10 \mathrm{~m}$ (Locus $\mathrm{B}$ ). No evidence of depth is available, although the deposit appears to be restricted to the surface. The total number of objects is greater than 100 , with density reaching 35 per square meter. Artifacts recorded include crimped milk cans, sanitary cans, 
tobacco and snuff tins, planks of milled lumber, a license piste, aqua carnival glass, an amethyst carnival bowl, a can opener, a stoneware vase, an enameled bucket, and glass bottles. Based on these artifacts, the site appears to date from 1917 to 1935. The site is located in a broad, flat plain, where ground cover ranges from $60 \%$ to $80 \%$. Soils are fine eolian sand with rounded pebble inclusions. The site appears relatively intact, but no evidence of structures is present. These could have been removed during the Hanford cleanup, or the site may consist of isolated trash dumps.

H 3-13. This site consists of widely dispersed cans, porcelain, and glass fragments. It lies in a plowed field; therefore, most of the fragile objects have been broken. The railroad runs along the western edge of the site approximately $50 \mathrm{~m}$ away. An old road, trending east/west, marks the southem boundary of the site. The site measures $67 \mathrm{~m}$ by $20 \mathrm{~m}$, with depths possibly reaching $1 \mathrm{~m}$. Only 30 intact artifacts were discovered; however, fragments of glass and ceramics number into the hundreds. The maximum density of objects reaches 15 per square meter. Identified items include a shoe sole, nails, the base of a green glassware plate, glass bottles, pop bottle caps, can lids, canning jar lids, cans, and tins. Based on the manufacturing dates of these artifacts, the site dates from 1917 to 1930. Sediments are very fine eolian sands with pebble inclusions. The site appears to be a domestic refuse dump that has been plowed and disturbed by reactor construction and auxiliary developments such as the railroad line.

H3-14. This $89-\mathrm{m}$ by $8-\mathrm{m}$ site has a large scattering of household debris, largeiy composed of glass and porcelain fragments. An exposed wooden irrigation pipe was found $60 \mathrm{~m}$ north of the site. Based on this observation, the presence of trees, and the proximity of an overgrown road, the site appears to be the remains of a homestead. Artifact density exceeds 80 items per square meter, with a total of 300 objects noted. Among the artifacts recorded are nails, pieces of wood, peach pits, walnut shells, shoe soles, cans, a bottle cap opener, a belt buckle, a door hinge, and a lantem handle. No directly datable material was discovered. However, the wooden irrigation pipe indicates a post-1910 date, and the site was certainly abandoned in 1943. The site is situated in a broad inland flat that has been extensively disturbed by borrow activities. Sediments are homogeneous fine sands with no indication of depth.
45B N 435. This prehistoric archaeological site is a light-density shell scatter and a single stone artifact, situated in a sand blowout on the broad early Holocene river terrace that looks the Columbia River. The site measures $50 \mathrm{~m}$ by $19 \mathrm{~m}$; depth of the site is unknown, but is unlikely to be more than $1.5 \mathrm{~m}$. Material density is greater than 100 shells per square meter. A single CCS core, from a blocky, wom river cobble was the only artifact found. Based on the setting and the content, this site appears to date from the Cascade Phase. Ground cover is only $10 \%$. Sediments consist of eolian sand and widely scattered cobbles. Because only the deflated portions of the site are visible, the condition of the remainder of the site is unknown. The bulk of the site may be covered by the $100-\mathrm{F}$ frontage road and might be encapsulated there. 45BN435 is scheduled for test excavation in 1993.

45B N433. Site $45 B N 433$ is a discrete concentration of FCR, utilized cobble spalls, lithic debitage, and mammal bone fragments situated in a dune blowout overlooking the Columbia River. The blowout, which measures $50 \mathrm{~m}$ by $100 \mathrm{~m}$, developed on top of a high, broad terrace of early Holocene origin. Cultural material appears to extend beyond $1 \mathrm{~m}$ in depth. Fifty artifacts were recorded at a maximum density of 20 per square meter. Among the artifacts are primary and secondary CCS flakes, a milling stone or hopper-mortar base, several basalt cores, and two spalled cobble tools/cores. A single feature, consisting of a dense concentration of FCR, is present and may be the remains of a hearth or oven. Soils consist of coarse to very fine sand and strata of volcanic ash. No date has been established for this site, but association with volcanic ash indicates an age of nearly 7000 years. The site is dissected by an outfall line (now an underground radiation zone). Grading of the site surface and excavations to install the outfall line have impacted much of this site, although intact portions may exist below the surface. Test excavations are scheduled for FY 1993.

45B N432. This site consists of several hearth features eroding out of the surface of the early Holocene river terrace. Associated cultural material consists of concentrations of FCR, CCS debitage, and fragments of Margaritifera and Gonidea shell. The deposit does not exceed $1 \mathrm{~m}$ in depth and measures $115 \mathrm{~m}$ by $48 \mathrm{~m}$. More than 500 artifacts are present, with a maximum density of 50 per square meter. Soils consist of fine to very fine silty eolian sand. No date has been established for this site, but it may date to the Cascade Phase. The site 
has been extensively disturbed by reactor construction and waste storage operations; a radiologically controlled zone borders the southwest portion of the site. Test excavation is scheduled for FY 1993.

45BN431. This site is situated on a high, prominent terrace (shared with sites 45BN435, $45 \mathrm{BN} 433,45 \mathrm{BN} 432$, and 45BN431) overlooking a prominent slough (F Slough) near its upstream confluence with the Columbia River. Artifacts incuude sparsely scattered CCS debitage, Margaritifera shells, CCS cores, fragments of large mammal bone, cobble tools, and FCR. The site measures $85 \mathrm{~m}$ by $50 \mathrm{~m}$. The depth of the site is unknown; however, shell fragments and flakes observed in ant hills and rodent burrow backdirt suggests the possibility of some depth to the deposit. Artifacts number into the hundreds, yet the maximum density is only eight per square meter. Artifacts recorded include a CCS core, a bifacially retouched CCS flake, a basalt net weight, and five cobble tools/cores. No features were observed. Modern trash litters the surface of the site. No temporally Jiagnostic materials were located, so a site date is unknown at this time. The site has been impacted by nearby well drilling and other reactor operations, but subsurface materials may retain their integrity. Test excavation is scheduled for FY 1993.

\section{0-H AREA}

The 100-H Area is located entirely on a level gravel terrace of Pleistocene age (Figure 5). East of the area is a broad flood channel filled with Holocene sediment, but no younger surfaces occur in the operable unit per se. No new sites were recorded within the $100-\mathrm{H}$ operable unit. A total of $64 \%$ of the site (120 ha out of $186 \mathrm{ha}$ ) was surveyed. One site (45BN176), an ethnographic village site occupied by the Wanapum tribe until 1943, was previously recorded by Rice (1958). 45BN176, which is a part of the Locke Island Archaeological District (a National Register of Historic Places property), is depicted in several early 1940 s photographs. Three wood-lined storage cellars were excavated into the river bank, and a dugout canoe is shown along the shore. The cellars, which are the only part of the site in the project area, appear to lie beneath more than $1 \mathrm{~m}$ of fill. The remainder of the site occupies the low channel surface east of the project area. Apparently, this was a Wanapum fishing encampment in use until the Hanford Site was closed to the public. The site is scheduled for exploratory excavations in 1992.

\section{0-K AREA}

The 100-K Area consists of two high Pleistocene terraces and at least two flood-incised Holocene terraces (Figure 6). The uppermost terrace is nearly level (140 to $146 \mathrm{~m}$ above sea level) and probably was formerly capped by stabilized dunes. The surface now consists of cobbles, with numerous boulders of basalt. This terrace slopes at a gradient of 40:1 to the second Pleistocene level at between 130 and $135 \mathrm{~m}$ above sea level. Nearly level at its upper end, it is narrower and steeper downstream, forming part of a nearly continuous slope from the upper terrace surface to the Columbia River. Eolian sediment makes up much of the surface of this terrace, which has a cobble and gravel substrate. The older of two Holocene surfaces lies at an elevation of $125 \mathrm{~m}$. This terrace consists entirely of massive fluvial sand with a depth of at least $2 \mathrm{~m}$. The $1.6-\mathrm{km}$-long terrace has a maximum width of $100 \mathrm{~m}$. A second terrace remnant of this same sediment occurs at the extreme downstream "nd of the area, separated from the upsiream $s$ inent by a ridge of boulders and the eolian sand trapped downwind of them. The lowest surface, at $121 \mathrm{~m}$, is discontinuous. Upstream it consists of cobbles and boulders that lie adjacent to Coyote Rapids. Downstream, where it occurs between the end of the older Holocene terrace and the boulder bar, it appears to have a thin, sandy veneer. In the latter area, a natural levee feature with an elevation of $123 \mathrm{~m}$ occurs. This feature consists of up to $1.5 \mathrm{~m}$ of fine sand, and is covered with driftwood from the 1948 flood of the Columbia River. Thirty-three percent, or 54 ha of 163 ha of the 100-K Area was undisturbed (see Figure 5).

Five prehistoric sites and a single farmstead were found within the 100-K Area. Three of these (45BN423, 45BN434, and 45BN115) are assignable to the Cascade Phase, while 45BN424 and an as-yet undesignated site (HT-91-009) date from the ethnographic period (since 1805 A.D.). Site H3-10 is an early twentieth-century farming complex. Two previously recorded prehistoric sites, part of the Ryegrass Archaeological District, also fall within this operable unit's boundaries (45BN150, 45BN151) (Rice 1968). 


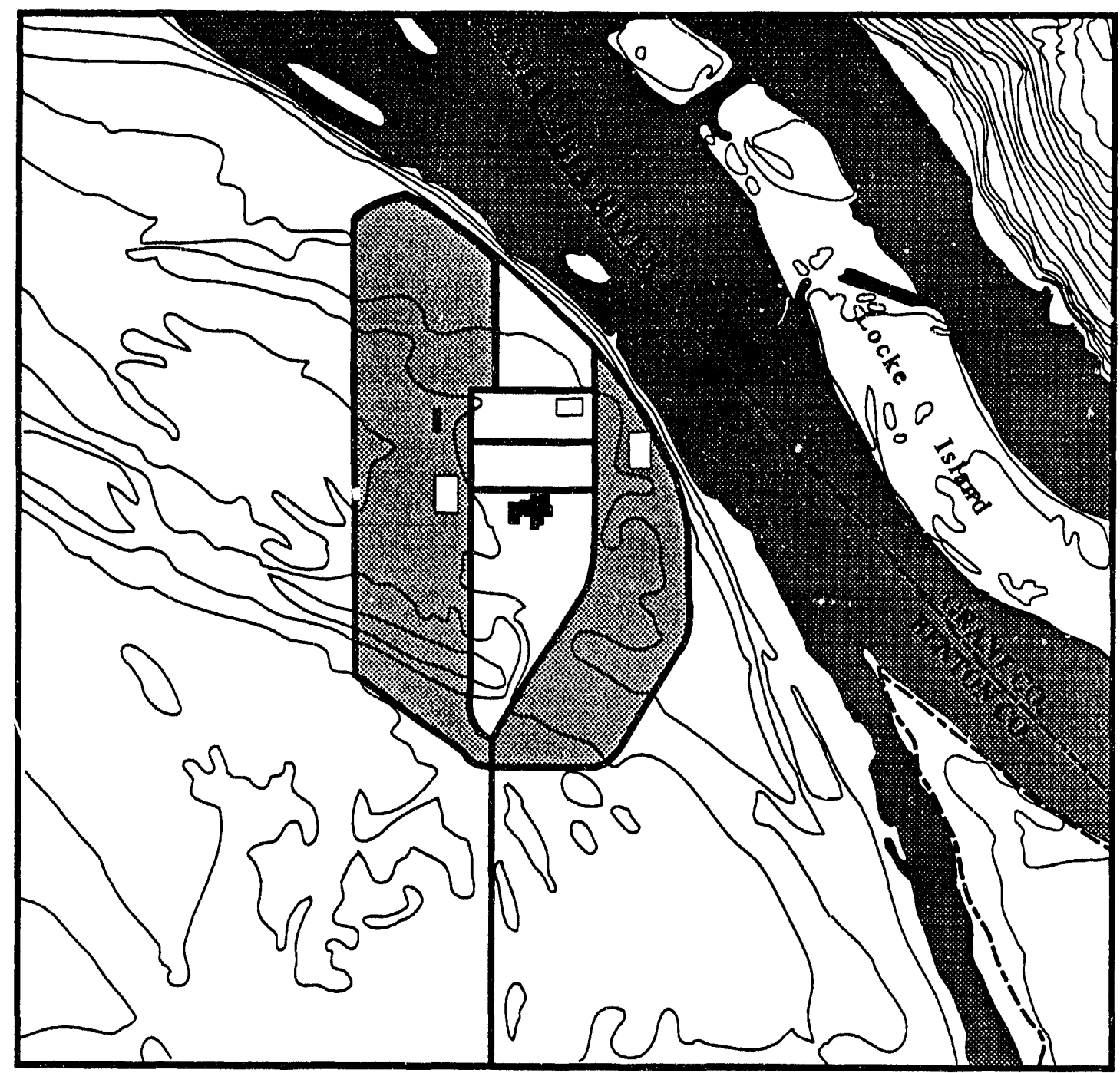

FIGURE 5. Areas Surveyed (Shaded) in the 100-H Area Shown on Portions of the U.S. Geological Survey Locke Island Quadrangle, T14N/R27E

45BN423. This early site consists of Margaritifera shell, FCR, basalt cobble cores, primary and secondary debitage from the cores, and tertiary flakes of petrified wood. The site lies $120 \mathrm{~m}$ from the river in the older Holocene terrace. Cultural material is buried by up to $1.5 \mathrm{~m}$ of fluvial sediments in the 3-m-deep sand of the terrace. It measures at least $260 \mathrm{~m}$ by $60 \mathrm{~m}$, but the maximum extent is unknown because the site extends beneath the water intake structures of the $K$ reactors and the boulder bench that lies between them. The density of cultural material reaches 50 items per square meter. The only features noted were concentrations of FCR. Based on its setting within a Holocene terrace and the nature and extent of the artifacts, this site appears to date from the late Cascade Phase or 4500-7000 years B.P. The site's general condition is quite good, impacted only by some erosion, rodent burrowing, and earth-moving activities. A radiation zone crosscuts the site near its upstream end, apparently marking an outfall pipe. This site is scheduled for testing in the summer of 1992.

45BN434. This site is also assignable to the Cascade Phase site and may actually be a continuation of 45BN423. Surface material consists of 


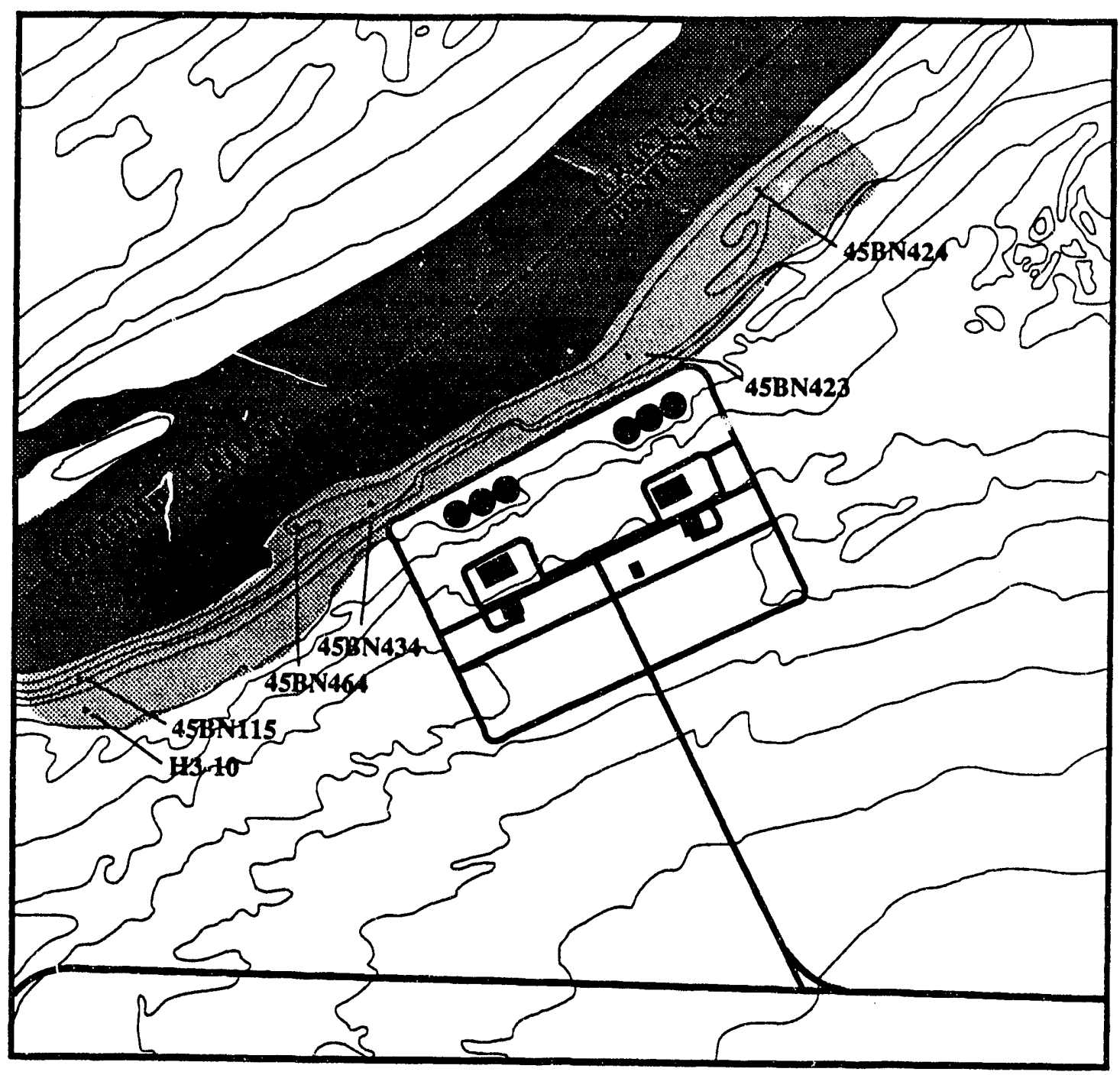

FIGURE 6. Areas Surveyed (Shaded) in the 100-K Area Shown on Portions of the U.S. Geological Survey Coyote Rapids Quadrangle, T13 \&14N/R26E

principally debitage; a more complex buried component is exposed in two borrow pits on the upstream end of the 100-K Area. The site, which measures $160 \mathrm{~m}$ by $100 \mathrm{~m}$, is confined to the same Holocene terrace as 45BIN423. The terrace surface is bordered on the north by a well-developed stand of black locust trees, backed by a steep, 4-m-high terrace bank, and truncated on the downstream end by the $\mathrm{K}$-west outfall line. Fine silty sand with rounded gravel inclusions are the principal sediments. Buried material, consisting of large Gonidia shells, quartzite and basalt cores, FCR, and cobble tools extends at least $75 \mathrm{~cm}$ below the surface based on exposures within the borrow pits. More than 200 artifacts were observed altogether, including one Cascade-style projectile point, cores of basalt and quartzite, cobble tools, and retouched CCS flakes. CCS debitage consists of primary, tertiary, and bifacial thinning flakes. The only feature observed consisted of a pronounced shell lens in the wall of a borrow pit. Disturbances include a recently constructed boat launch and two borrow pits. This site is scheduled for testing in 1992.

45BN115. Site 45BN115 is situated on a $50-\mathrm{m}$ by $100-\mathrm{m}$ remnant of the earlier Holocene terrace, just downstream of the Allard pumping plant. Cultural material is eroding out of the terrace bank to depths of $1.2 \mathrm{~m}$, suggesting that the site may be stratified. Soils are a sandy silt loam with depths to $2 \mathrm{~m}$. Artifacts, which occur in very low densities, consist of discrete concentrations of 
FCR and Gonidea shell. At least one in situ hearth was noted and could provide materials for dating the site by radiocarbon assay. The site is dissected on the west by an old road to the pumphouse, which has destroyed much of the cultural deposit. This site has not been scheduled for testing, because it lies well upstream of anticipated cleanup activities.

45BN424. This is the most complex archaeological site discovered during survey of the 100 areas. The site begins near the upstream end of the late Holocene natural levee as a dense scatter of FCR decreasing in density until seven shallow house pits are encountered. One depression, which is marked by piles of FCR along its edges, apper's to the remains of a sweat lodge. A long oval depression may be a remnant long house. Downstream of this group of features is a buried artifact deposit occurring in what appears to be a portion of the older Holocene terrace. Artifacts include hoppermortar bases, hammer stones, and numerous cobble cores. The site measures $125 \mathrm{~m}$ north/ south by $375 \mathrm{~m}$ southwest/northeast, encompassing the entire natural levee and a portion of an older terrace.

This site fits the description of a nineteenthcentury Wanapum village located near Coyote Rapids (Relander 1956), where the Washane prophet Smohala held the first dance of the revitalized traditional religion that is now practiced by many members of the Yakima, Umatilla, and Warm Springs tribes, as well as the Wanapum. The site's proximity to an historic Wanapum cemetery (site 45BN151) lends support to this suggestion. The downstream portion of this site contains artifacts that may be much older, perhaps dating to the middle prehistoric Frenchman Springs Phase (2500-4500 B.P.). Interviews with Native American informants and minor test excavations are planned for this site to verify its age and historical significance.

HT-91-009. This site, which does not yet have a state number, is bracketed by an embayment to the west (upstream), a pronounced gravel bar to the north (riverside), a high $(4 \mathrm{~m})$ terrace south (inland), and a lower terrace to the east (downstream). The site, which measures $240 \mathrm{~m}$ by $200 \mathrm{~m}$, can only be described as a pavement of FCR. While some cobble tools and spall knives are present, FCR is the dominant cultural item. Artifacts appear to be entirely confined to the surface a densities exceeding 150 pieces of FCR per square meter. Several shallow depressions marked by large boulders occur and may be of cultural origin. This property is structurally unique for the Hanford Site. No other FCR concentrations of this magnitude have been recorded. Based on ethnographic descriptions and the site's position adjacent to Coyote Rapids, this may be a fish processing station that was occupied by members of the Wanapum tribe. Apparently, gravel beaches were favored locations for fish processing because such settings made it easier to keep sand off of the fish. The depressions noted could very well be the locations of drying racks or temporary sleeping areas. Further investigation is warranted, although no test excavations have been scheduled.

H3-10. This is a homestead and field complex (circa 1925), located on the lower Pleistocene terrace. Several old cars and distinct activity loci are apparent, as are crop marks in the old fields. Including the remnant fields, the site measures $500 \mathrm{~m}$ east/west by $150 \mathrm{~m}$ north/south. The Hanford ditch forms the western and southern boundaries of the site. The field is well delineated by crop marks and linear piles of field stones. The site is mostly confined to the surface, although a collapsed cellar is located on the northem boundary. The majority of artifacts are concentrated along the north margin between the terrace edge and the field boundary. Artifacts include car bodies dating from between 1915 and 1929, a buckboard wagon, parts from a wood-burning stove, barrel hoops, a cider press, and miscellaneous shop and household debris. There are four distinct loci, one with household material, one with incinerator parts and ash, a collapsed cellar, and an outbuilding or shop scatter. The site has been extensively impacted by heavy equipment, probably during the Hanford cleanup. This site represents an era of settlement that has been largely ignored. While partially disturbed, the site retains distinct activity areas and excellent preservation. Because of its proximity to the Hanford ditch and pumphouse, it may be part of the ditchkeeper's holdings. A literature and records search is scheduled for August 1992.

\section{0-N AREA}

The 100-N Area lies in a concentration of berg mounds on a high Pleistocene terrace (Figure 7). The vicinity of the reactor compound itself was originally either level or has been leveled from the berg mounds. The terrace surface averages $140 \mathrm{~m}$ above sea level and berg mounds range up to $150 \mathrm{~m}$. The terrace slope is high and steep, with a 


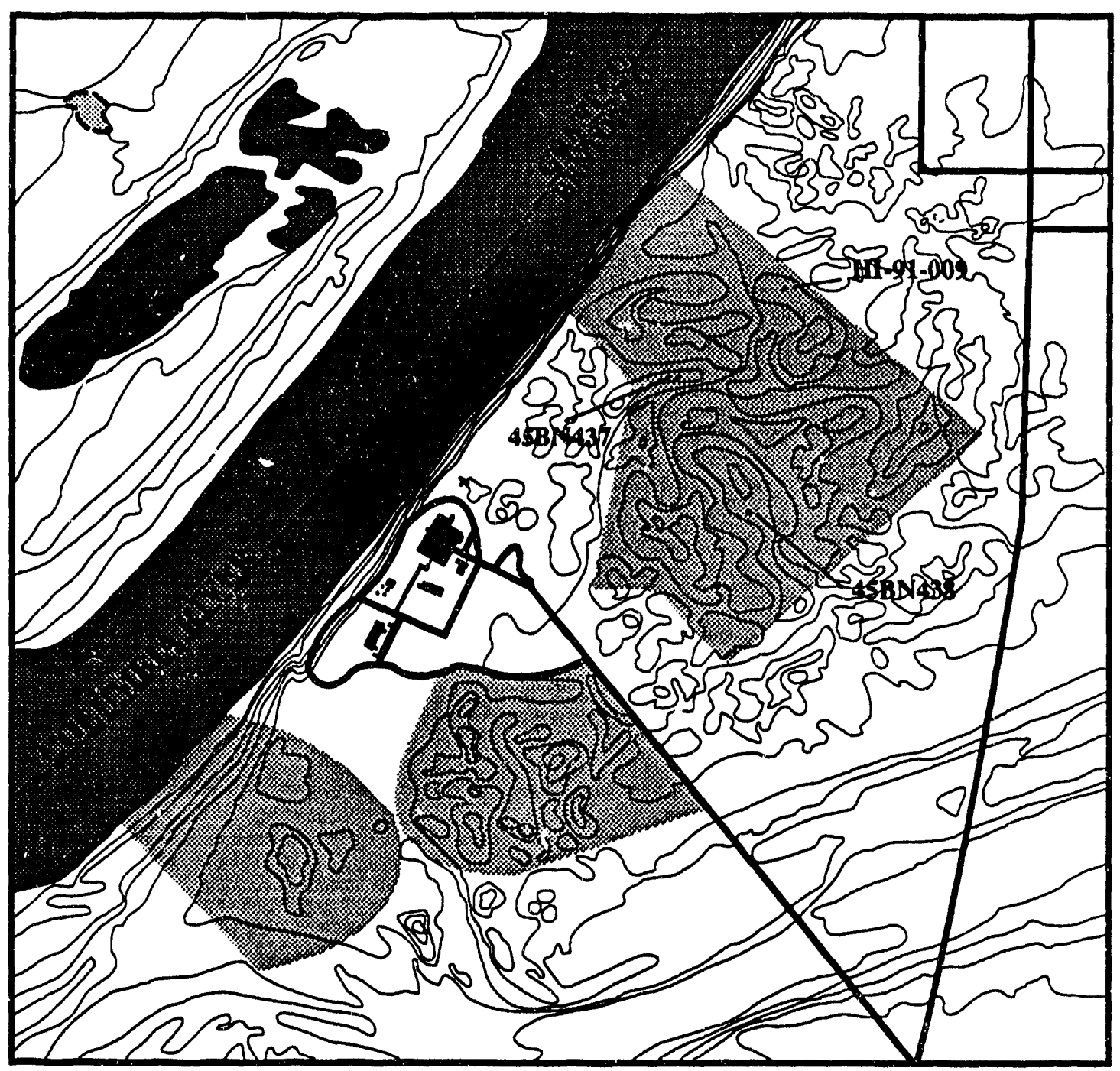

FIGURE 7. Areas Surveyed (Shaded) in the 100-N Area Shown on Portions of the U.S. Geological Survey Coyote Rapids Quadrangle, T13 \& 14N/R26E

gradient of 5:2. A portion of the older Holocene terrace described for the $100-\mathrm{K}$ Area continues to the upstream edge of this operable unit (where archaeological sites 45BN179 and 45BN180 occur). In this area the terrace is $25 \mathrm{~m}$ wide and has an elevation of $122 \mathrm{~m}$ and an approximate depth of 1.5 to $2.0 \mathrm{~m}$. A second $400-\mathrm{m}$ by $75-\mathrm{m}$ elliptical remnant of this terrace lies downstream. A total of 209.45 ha $(49 \%)$ was surveyed of the 425 ha within this unit's boundaries.
Three previously recorded sites (45BN180, Two sites (45BN437 and 45BN438), both cairns, were recorded in the berg mound area. 45BN149, and 45BN179) are also located within the unit.

45BN437. Similar to those caims described in 100-DR-1, 45BN437 is situated on the apex of a rounded berg mound. This single $1-\mathrm{m}^{2} \mathrm{caim}$ is composed of basalt boulders $70 \%$ to $90 \%$ covered with lichen. 
45BN438. This caim is composed of approximately 16 boulders, the majority of which are basali. Two granite boulders are located near the cente of the caim. Lichen growth is $50 \%$ to $70 \%$.
Dimensions of the caim are $0.5 \mathrm{~m}$ by $0.8 \mathrm{~m}$ by $0.3 \mathrm{~m}$. Like others described, the cairn is situated on berg mound. 


\section{SUMMARY AND CONCLUSIONS}

During spring and summer of 1991, the HCRL conducted a literature review and archaeological survey of the 100 Area reactor compounds and adjacent Columbia River shorelines on the Hanford Site. The areas in question, including the $100-\mathrm{B} / \mathrm{C}, 100-\mathrm{D}, 100-\mathrm{F}, 100-\mathrm{H}, 100-\mathrm{K}$, and $100-\mathrm{N}$ areas, cover a total of $1834 \mathrm{ha}$, of which 770 ha remained undisturbed enough to warrant archaeological survey. Altogether, 30 sites and one isolated artifact occur in the project areas, including six sites that had been recorded previously and are listed on or considered eligible for the National Register of Historic Places. Of the sites, six are attributable to Euro-American farming activity during the early twentieth century. The remainder are from Native American occupation, dating from as early as 7000 B.P. to the middle of the twentieth century A.D.

Nineteen of the sites are situated on low terraces adjacent to the Columbia River, or on high terraces at the immediate river bank. Ten, including five of the six historic sites, are located on the high terraces occupied by $r$ actor facilities. One site (45BN176) covers parts of both. Sites on the higher terrace, including Euro-American sites $\mathrm{H} 3-10, \mathrm{H} 3-12, \mathrm{H} 3-13, \mathrm{H} 3-14$, and $\mathrm{H} 3-17$, and Native American sites 45BN437, 45BN438, $45 \mathrm{BN} 442,45 \mathrm{BN} 443$, and 45BN444 are at a higher risk of impact during CERCLA characterization studies. Also at high risk are seven sites that lie adjacent to or are intersected by radiation zones along the river floodplain, including 45BN150, 45BN151, 45BN423, 45BN424, 45BN432, 45BN433, and 45BN439. Three additional sites--45BN431, 45BN435, and 45BN446--are close to frontage roads or launch facilities and may receive indirect impacts.

Evaluation of the significance of all sites discovered in FY 1991 will be conducted in FY 1992 and 1993. The DOE is currently considering negotiating a programmatic Agreement with the Washington State Historic Preservation Office, the Advisory Council for Historic Preservation, and affected Native American Tribes to aid in mitigation of affects to significant historic properties that are within or affected by contamination from CERCLA operational units. There are currently no guidelines available to assist us in this matter. In the interim, all excavation work and road building associated with CERCLA characterization of the 100 Areas will be reviewed by HCRL and DOE personnel and plans will be adjusted by Westinghouse Hanford Company to avoid impacts to cultural resources whenever possible. Cases where this is not possible are nut foreseen at this writing. 


\section{REFERENCES}

Chatters, J. C. 1989. Hanford Cultural Resources Management Plan. PNL-6942, Pacific Northwest Laboratory, Richland, Washington.

Chatters, J. C., N. A. Cadoret, and P. E. Minthorn. 1990. Hanford Cultural Resources Laboratory Annual Report for Fiscal Year 1989. PNL-7362, Pacific Northwest Laboratory, Richland, Washington.

Chatters, J. C., H. A. Gard, and P. E. Minthorn. 1991. Hanford Cultural Rusources Laboratory Annual Report for Fiscal Year 1990. PNL-7853, Pacific Northwest Laboratory, Richland, Washington.

Lohse, E. S. 1985. "Rufus Woods Lake Projectile Point Chronology." In Summary of Results, Chief Joseph Dam Cultural Resources Project, Washington, ed. S. K. Campbell, pp. 317-364. Office of Public Archeology, University of Washington, Seattle.

Relander, C. 1956. Drummers and Dreamers. Caxton Printers, Caldwell, Idaho.

Rice, D. G. 1968. Archaeological Reconnaissance: Ben Franklin Reservoir Area, 1968.

Washington State University, Laboratory of Anthropological Studies, Pullman, Washington.

Rice, D. G. 1983. Cultural Resources at Hanford. Washington Power Supply System and U.S. Department of Energy, Richland, Washington.

Trafzer, C. E., and R. D. Scheuerman. 1986. Renegade Tribe: The Palouse Indians and the Invasion of the Inland Pacific Northwest. WSU Press, Pullman, Washington. 


\section{DISTRIBUTION}

No. of

Copies

\section{OFFSITE}

2 DOE/Office of Scientific and Technical Information

State Historic Preservation Officer Office of Archaeology \& Historic

Preservation

111 West 21st Ave., KL-11

Olympia, WA 98504-5411

D. Hogan

U.S. Army Corps of Engineers

Box C-3755

Seattle, WA 98124-2255

D. Canty

National Park Service, Pacific

Northwest Region

83 King St., Suite 212

Seattle, WA 98104

J. Leier

U.S. Army Corps of Engineers

Walla Walla District

Building 602, City-County Airport

Walla Walla, WA 99362-9265

B. Crespin

U.S. Bureau of Land Management

Bums, OR 97720

2 Colville Confederated Tribes

Attn: Tribal Council A. Fredin

P.O. Box 150

Nespelem, WA 99155

2 Nez Perce Tribe

Attn: Tribal Council

A. Slickpoo

P.O. Box 305

Lapwai, ID 83540
No. of

Copies

2 The Confederated Tribes of the Umatilla Indian Reservation

Attn: Tribal Council

$$
\text { J. Van Pelt }
$$

P.O. Box 638

Pendleton, OR 97810

2 The Wanapum Indian Tribe

Attn: Tribal Council

$$
\text { R. Buck, Jr. }
$$

P.O. Box 275

Beverly, WA 99321

2 The Yakima Indian Nation

Attn: Tribal Council

B. Yallup

P.O. Box 151

Toppenish, WA 98948

3 Washington Department of Ecology 99 S. Sound Center

Lacey, WA 98504

C. Cline

S. F. Cross

L. Goldstein

D. Teel

Washington Department of Ecology

7601 W. Clearwater

Kennewick, Washington 99336

\section{ONSITE}

24 DOE, Richland Field Office

P. F. Dunigan

A5-15

E. D. Goller (10)

A5-19

J. D. Goodenough

A5-19

N. M. Highland

A7 -27

M. B. Hitt

A7-27

R. D. Izatt

A5-15

C. R. Pastemak (5)

A7-27

Distr.1 
No. of

Copies

E. E. Pride

A4-52

J. R. Shadel

A5-90

DOE Legal Library

A4-78

Public Reading Room

Al-65

4 U.S. Environmental Protection Agency

P. R. Beaver

B5-01

D. A. Faulk

B5-01

L. E. Gadbois

B5-01

P. S. Innis

B5-01

34 Westinghouse Hanford Company

M. R. Adams

H4-55

J. M. Ayres

H4-55

J. R. Culmer

XO-21

R. E. Day

H4-55

R. H. Engelmann

H4-57

T. W. Ferns

H4-57

G. E. Fitzgibbon

K. A. Gano

M. S. Gerber

W. R. Green

R. H. Griffin

R. P. Henckel

W. L. Johnson

A. D. Krug

D. S. Landeen

M. J. Lauterbach

R. M. Mitchell

N. M. Naiknimbalkar

J. W. Roberts

H4-55
No. of

Copies
F. V. Roeck
M. R. Sackschewsky
H4-55
M. T. Stankovich
H4-55
S. E. Vukelich
H4-55
H4-55
D. J. Watson
R. S. Weeks
$\mathrm{XO}-41$
H4-57
S. G. Weiss (5)
H4-55
Central Files
L8-04
EDMC (3)
H4-22

44 Pacific Northwest Laboratory

T. L. Brown

J. C. Chatters

H. A. Gard (11)

J. M. Gephart

R. H. Gray

R. E. Jaquish

J. G. Longenecker (20)

L. E. Rogers

Publishing Coordination

Technical Report Files (5)

$\mathrm{K} 1-55$

P7-54

P7-54

K6-86

K1-33

$\mathrm{K} 1-30$

P7-54

Routing

R. M. Ecker

P. M. Irving

J. W. Falco

M. J. Graham

C. J. Hostetler

R. L. Skaggs

C. S. Sloane

P. C. Hays (last)
MSL/Sequim

K6-98

K6-78

K6-80

K6-81

K6-77

K6-04

K6-86

Distr.2 

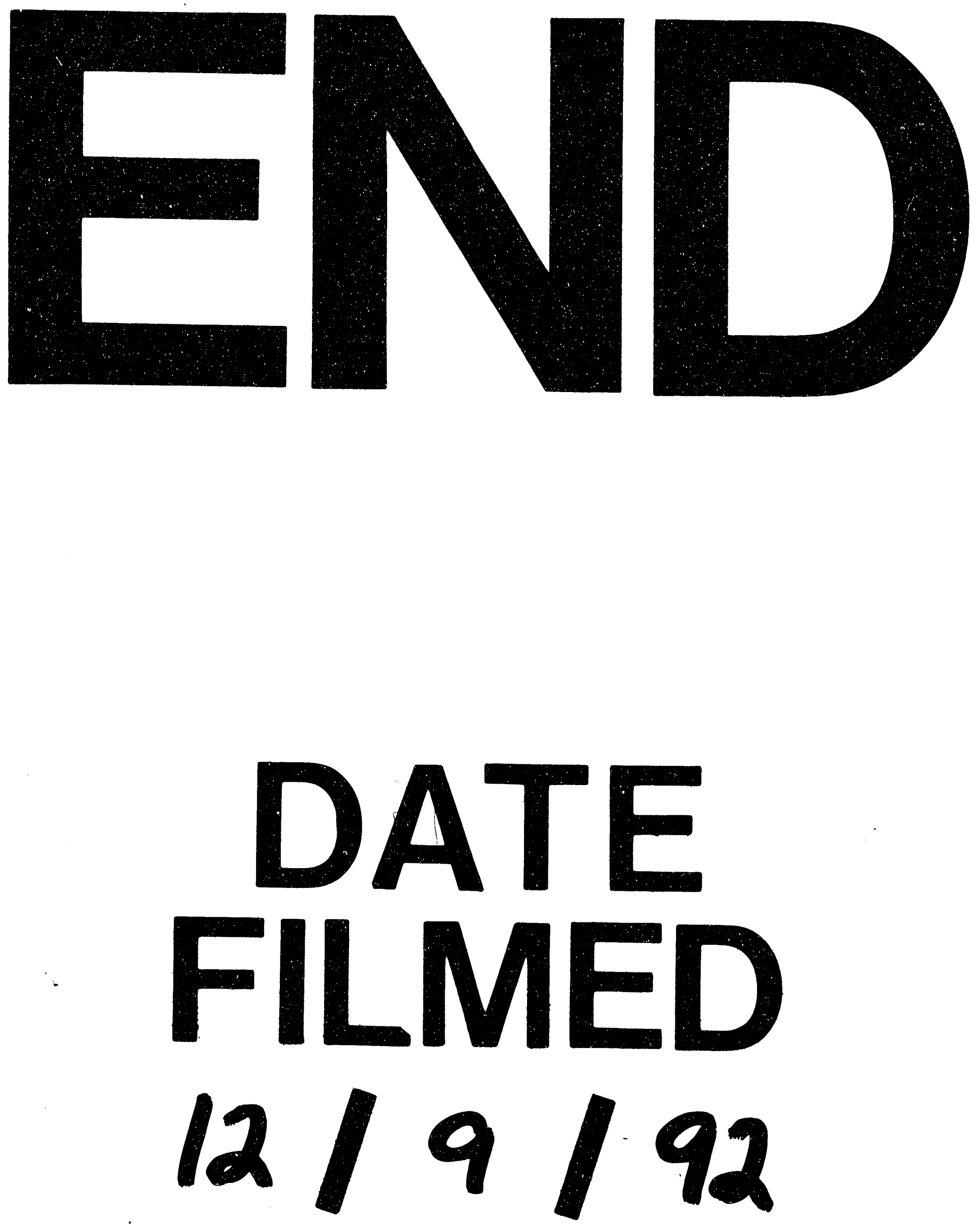
